УДК $77.031 .05 ; 77.03 .08$

\title{
ЦИФРОВЕ ФОТО З ЕКСПЕРИМЕНТАЛЬНИМ ДОСЛІДЖЕННЯМ ТЕХНОЛОГІЇ ОБРОБЛЕННЯ
}

ㄷ Д. О. Івженко, магістр, Р. А. Хохлова, к.т.н., доцент, НТУУ «КПІ», Київ, Україна

Проанализированы существующие технологии фотографирования и обработки цифровых фото, а также систематизированы факторы, которые влияют на конечный продукт.

There was analysed current technologies of creating digital photography and editing photos and systemazed factors that affect the final product.

\section{Постановка проблеми}

Цифрова фотографія (ЦФ), як одиниця мультимедійного простору, посідає дедалі більш значуще місце у сучасному світі та має певне призначення, спрямованість, особливість, сюжет. Створена автором цифрова фотографія має свою оригінальність із наявними дефектами, нюансами тощо, проте процес оброблення та редагування фото за допомогою відповідного програмного та апаратного забезпечення вносить покращення у загальне сприйняття зафіксованої інформації, приховує або виправляє недоліки. Проте процес оброблення часто $\epsilon$ кропітким, індивідуальним, тривалим та циклічним із повторенням одних і тих же операцій для кожного фото. Саме тому актуальним $€$ вивчення існуючих технологій оброблення цифрової фотографії та їх вдосконалення 3 метою спрощення та скорочення процесу обробки.

\section{Аналіз попередніх}

\section{досліджень}

За оцінками фахівців ЦФ $€$ невід'ємною ланкою сучасного життя [1]. Саме тому існують різноманітні технології фотографування [2], спеціальне обладнання для створення фотографій різними методами та велика кількість різноманітного за способами дії та можливостями програмного забезпечення для проведення коригування та оброблення ЦФ. Відомо, що на якість фото впливають спосіб його створення та оброблення, проте досі не було досліджено яким чином ці технології визначають якість готового продукту та чим необхідно маніпулювати для досягнення найкращого результату [3]. Також на сьогодні відсутня чітко сформульована стандартна технологія створення фотографічних зображень, виходячи із обраних головних чинників впливу на якість готової продукції.

Послідовність дій при обробленні ЦФ відіграє досить важливу роль, адже кожний виконаний крок впливає на наступні кроки - правильний підхід до виконання певних операцій гарантує успіх в цілому [4]. Саме тому актуальним є розроблення детального алгоритму процесу оброблення ЦФ [5]. 
ЦФ за своєю структурою є растровим зображенням [6]. Для таких ілюстрацій існує велика кількість графічних редакторів, серед яких найбільшою популярністю користується Adobe Photoshop. Також існує велика кількість форматів для збереження готового фото [6, 7], проте не встановлено головні переваги та недоліки кожного з них, аби обрати найбільш відповідний.

\section{Мета роботи}

За мету роботи було поставлено проведення аналізу та систематизації параметрів, що впливають на якість ЦФ; здійснення аналізу апаратного та програмного забезпечення (АЗ та ПЗ) для створення та оброблення ЦФ; розроблення відповідного технологічного процесу створення та детального алгоритму оброблення ЦФ на підставі обраного АЗ та ПЗ.

\section{Результати проведених досліджень}

Дослідження, аналіз та систематизація можливих чинників, що впливають на якість ЦФ, дають можливість передбачати та зменшувати втрати якості, допомагають вирішенню задач щодо поліпшення якості. Втрати якості закономірно пов'язані 3 технологічними процесами, матеріалами, що використовуються, обладнанням, метрологією процесу, цеховими умовами, роботою персоналу. Обираючи систему контролю якості оброблених ЦФ слід узгоджувати технологію алгоритмів оброблення з індивідуальними технологічними режимами створення, влас- тивостями обладнання та матеріалів. Для упорядкування чинників, що впливають на якість ЦФ було здійснено аналіз науково-фахової літератури та опитування спеціалістів галузі виготовлення та оброблення ЦФ й на основі отриманих даних розроблено причинно-наслідкову діаграму (рис. 1).

Серед загалу зазначених факторів, що впливають на якість ЦФ було обрано вісім найбільш впливових й проведено їх експертне оцінювання спеціалістами галузі. На основі отриманих даних побудовано матрицю експертних оцінок та діаграму Парето (рис. 2). Так, найбільш впливовими виявились характеристики цифрового фотоапарату, кваліфікованість фотографа та обране програмне забезпечення для обробки ЦФ.

Як свідчить рис. 2, при формуванні ЦФ характеристики цифрового фотоапарату мають визначну роль. Для визначення найвпливовіших характеристик експертами було здійснено їх оцінювання (рис. 3). Так, за оцінками фахівців, найбільше значення при виборі цифрового фотоапарату мають розмір матриці та її роздільна здатність (кількість мегапікселів).

Цифрова фотографія по своїй структурі $€$ растровим зображенням, тому для її оброблення застосовують різного роду растрові графічні редактори, найбільш поширеними з яких є: Helicon Filter, Adobe Photoshop, Corel PHOTO-PAINT, GIMP. 3aзначені програмні продукти $€$ дещо схожими за своїми можливостями та інструментами. Для визначення 

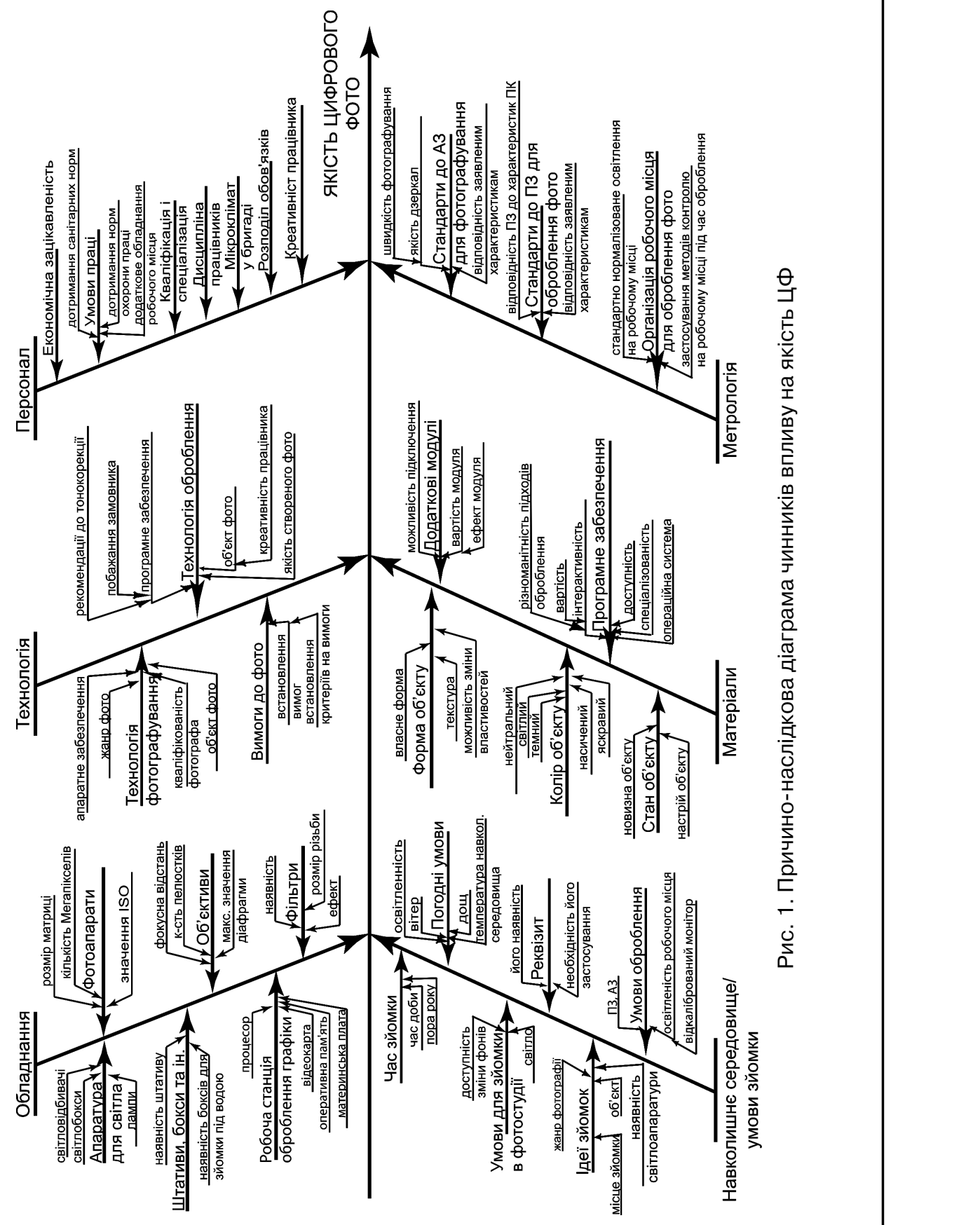


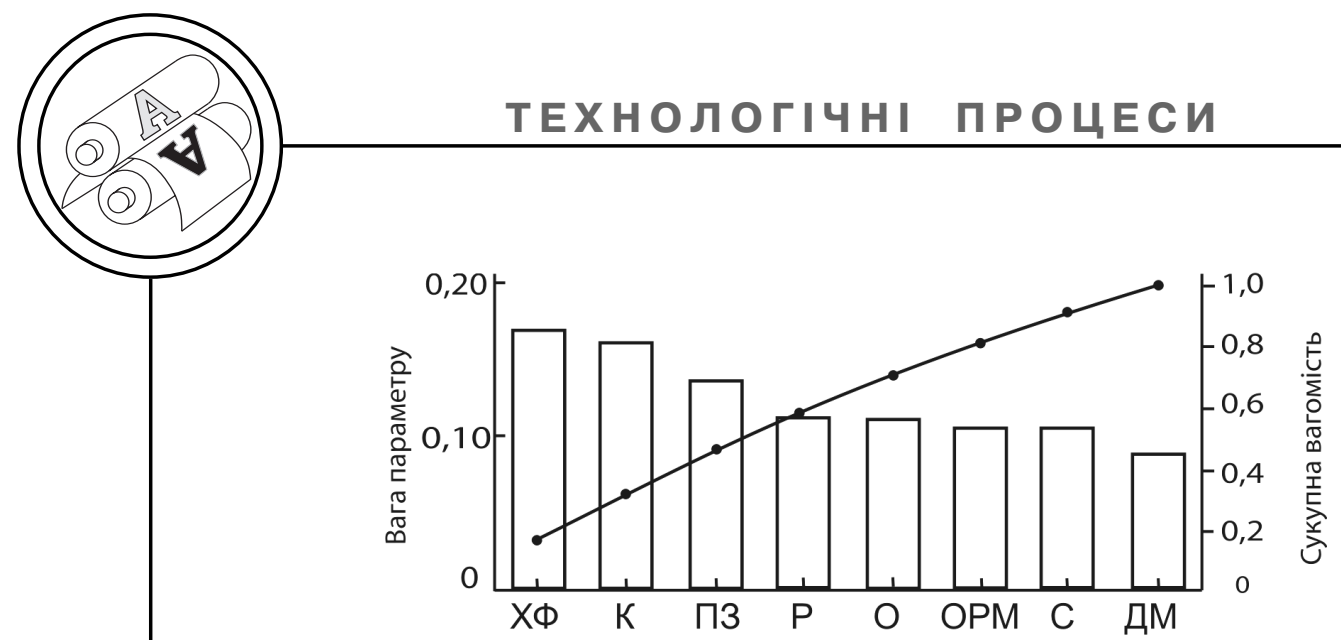

Рис. 2. Аналіз чинників впливу на якість ЦФ, де: ХФ - характеристики цифрового фотоапарату; К - кваліфікованість фотографа; ПЗ - програмне забезпечення для обробки ЦФ; Р - різноманітність підходів оброблення;

О - освітленість при зйомці; ОРМ - освітленість робочого місця;

C - світлоапаратура; ДМ - можливість підключення додаткових модулів

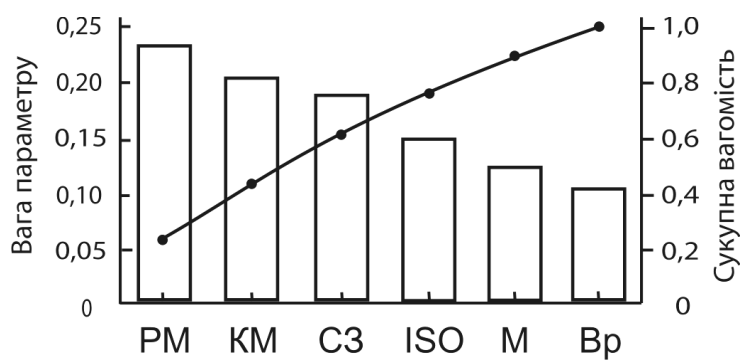

Рис. 3. Аналіз чинників впливу на вибір цифрового фотоапарату, де:

PM - розмір матриці; КМ - кількість мегапікселів; СЗ - кількість серійних знімків; ISO - мінімальне значення ISO; M - мaca; Вp - вартість

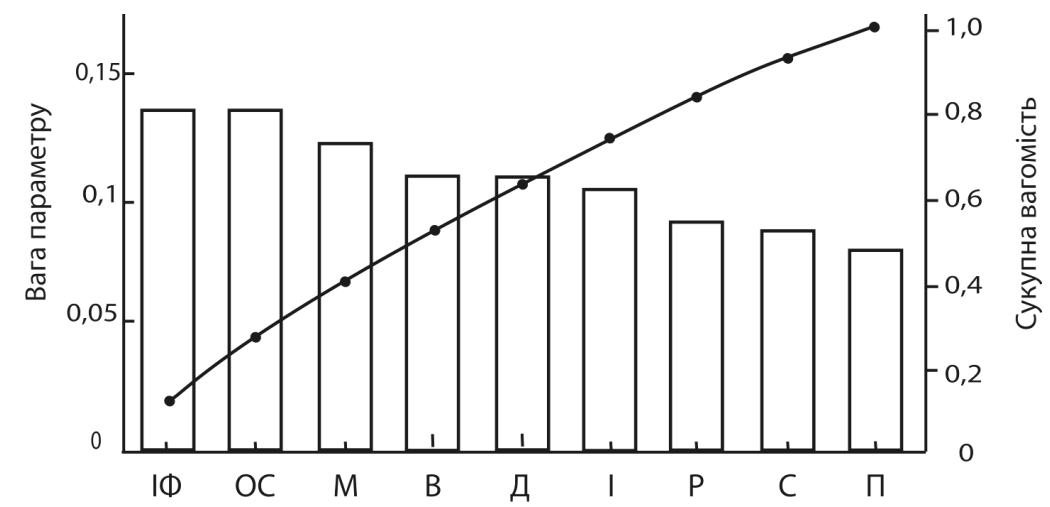

Рис. 4. Аналіз чинників впливу на вибір растрового графічного редактору, де: ІФ - імідж фірми-виробника; ОС - операційна система; М - можливість підключення допоміжних програм; В - вартість; Д - доступність; I - інтерактивність; Р - різноманітність підходів обробки; C - спеціалізованість; П - простота роботи 


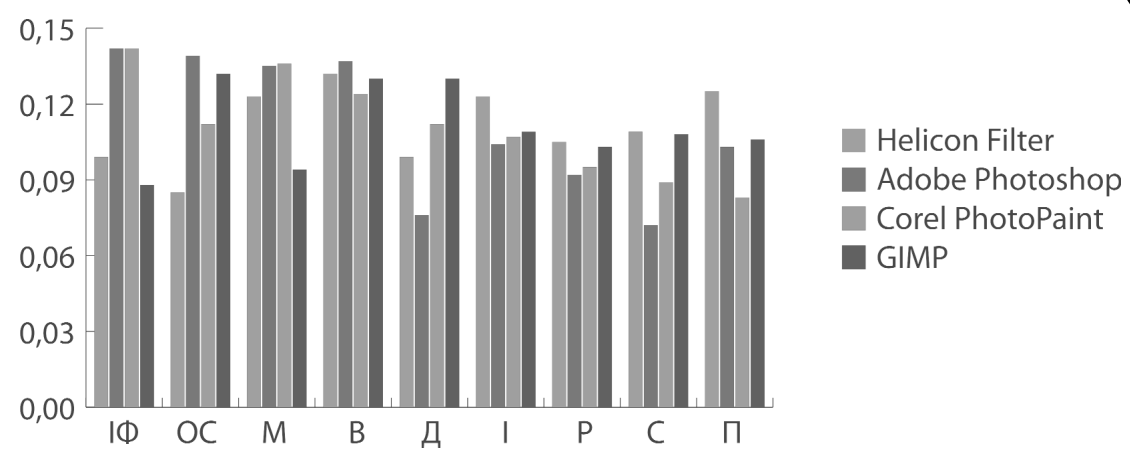

Рис. 5. Аналіз растрових графічних редакторів

параметрів, що впливають на вибір растрового редактора експертам було запропоновано складену матрицю, за результатами обробки якої побудовано діаграму Парето (рис. 4). Встановлено, що при виборі растрового графічного редактору для обробки ЦФ мають суттєвий вплив: імідж фірми-виробника, можливість використання програми в різних операційних системах та можливість підключення до неї допоміжних утиліт, програм.

Отримані дані з ранжування найвпливовіших факторів при виборі растрового графічного редактору застосовано для аналізу зазначеного програмного забезпечення, який обґрунтовує масове використання редактору Adobe Photoshop для обробки ЦФ (рис. 5).

Процес фотографування $\epsilon$ доволі складним через багатий вибір всіх складових, які в кінцевому результаті можуть вплинути на готове зображення. Тому важливим $€$ встановлення найбільш прийнятної послідовності усіх операцій з їх повсякчасним контролем. На основі аналізу науково-фахової літератури та опитування спе- ціалістів галузі було розроблено загальну блок-схему технологічного процесу створення ЦФ (рис. 6).

Для досягнення найкращого результату файли з камери зазвичай розцінюють як сирий матеріал, що вимагає подальшої інтерпретації. Кожна цифрова фотографія потребує певної послідовності операцій для її оброблення. Так, кожний крок має вплив на наступні, а отже необхідно чітко встановити алгоритм дій для проведення найбільш швидкого, та водночас найбільш якісного процесу оброблення. На виконання цієї вимоги було розроблено детальний алгоритм процесу оброблення ЦФ в ручному режимі (рис. 7), особливістю якого є те, що більшість операцій можливо виконати великою кількістю способів. Саме жанр фото, його вид, умови зйомки та технічні характеристики впливають на вибір того чи іншого способу виконання операції та на її результат в цілому.

Експериментальне дослідження технології оброблення полягає в розробленні макросу, який дозволяв би уникнути виконання однотипних операцій. 


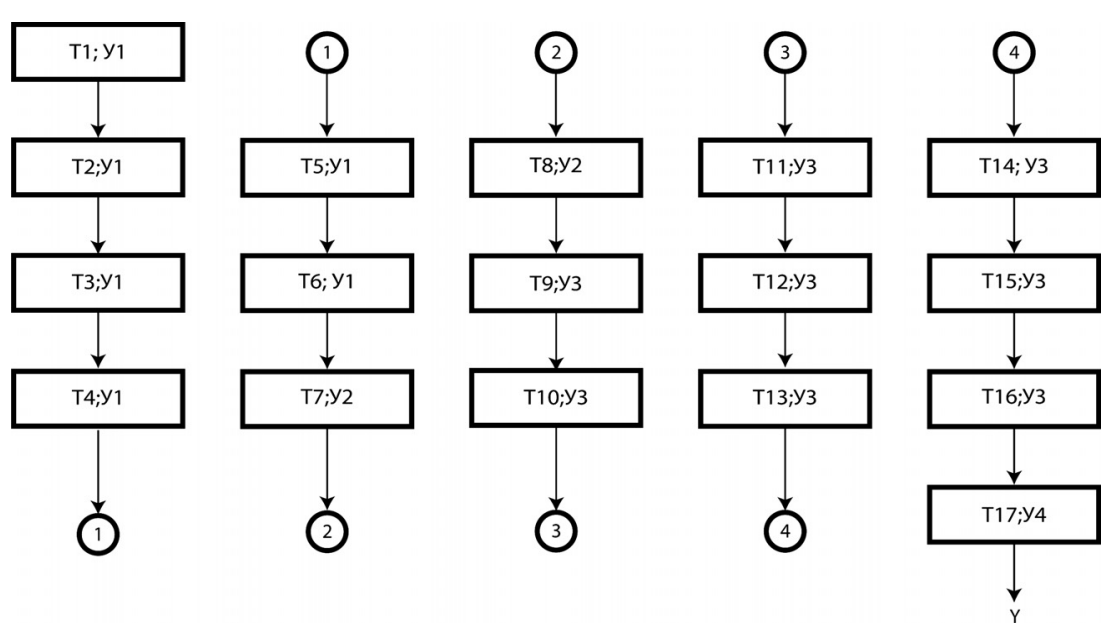

Рис. 6. Технологічний процес створення ЦФ, де Т1 - визначення та встановлення вимог до готового фото; Т2 - вибір жанру;

Т3 - визначення та встановлення вимог до об'єкту; Т4 - вибір об'єкта, Т5 - визначення критеріїв для вибору умов фотографування; Т6 - вибір умов створення фотографії; Т7 - вибір об'єктива; Т8 - пробний знімок

для визначення необхідних налаштувань; Т9 - налаштування світла;

Т10 - налаштування фотоапарату; Т11 - пробний знімок; Т12 - зміна налаштувань фотоапарату, ракурсу зйомки, постановки плану зйомки;

Т13 - створення цифрових зображень; Т14 - встановлення відповідності готового фото вимогам; Т15 - зміна налаштувань фотоапарату, ракурсу зйомки, поставки плану зйомки; Т16 - створення цифрових зображень;

Т17 - збереження фотографій на ПК; У1 - дзеркальний фотоапарат Nikon D700; У2-У1 + обраний об'єктив; УЗ-У2 + апаратура для світла;

У4-У3 + ПК (AMD Athlon 64 X2 3800, 4 Гбайт ОЗП, 400 Гбайт 3ЗП, відеоадаптер ATI Radeon HD3870 з 512 Мбайт відеопам'яті, клавіатура, мережевий адаптер, роутер); Ү - цифрові фото на ПК

В такому випадку це призвело б до уникнення зменшення уваги спеціаліста з обробки та скорочення часу на оброблення одного фото. Найбільш доцільною завжди є розробка цілого шаблону без переривань для скорочення часу на виконання всіх операцій. Проте, наприклад, операція ретушування, що має місце в середині процесу оброблення, може виконуватись лише в ручному режимі. Оскільки цілісний шаблон не може мати переривання посеред процесу для виконання ручних опе- рацій, тому на основі використання макросів було розроблено комплекс шаблонів, які значно скорочують час на оброблення. Для встановлення кількісних переваг даної розробки проведено порівняння витраченого часу на оброблення одного і того ж ЦФ із використанням комплексу макросів та без ї залучення. На прикладі портретних зображень було встановлено, що комплекс макросів дозволяє скоротити час оброблення ЦФ з дев'ятнадцяти хвилин до дванадцяти (див. рис. 8). Таким чи- 


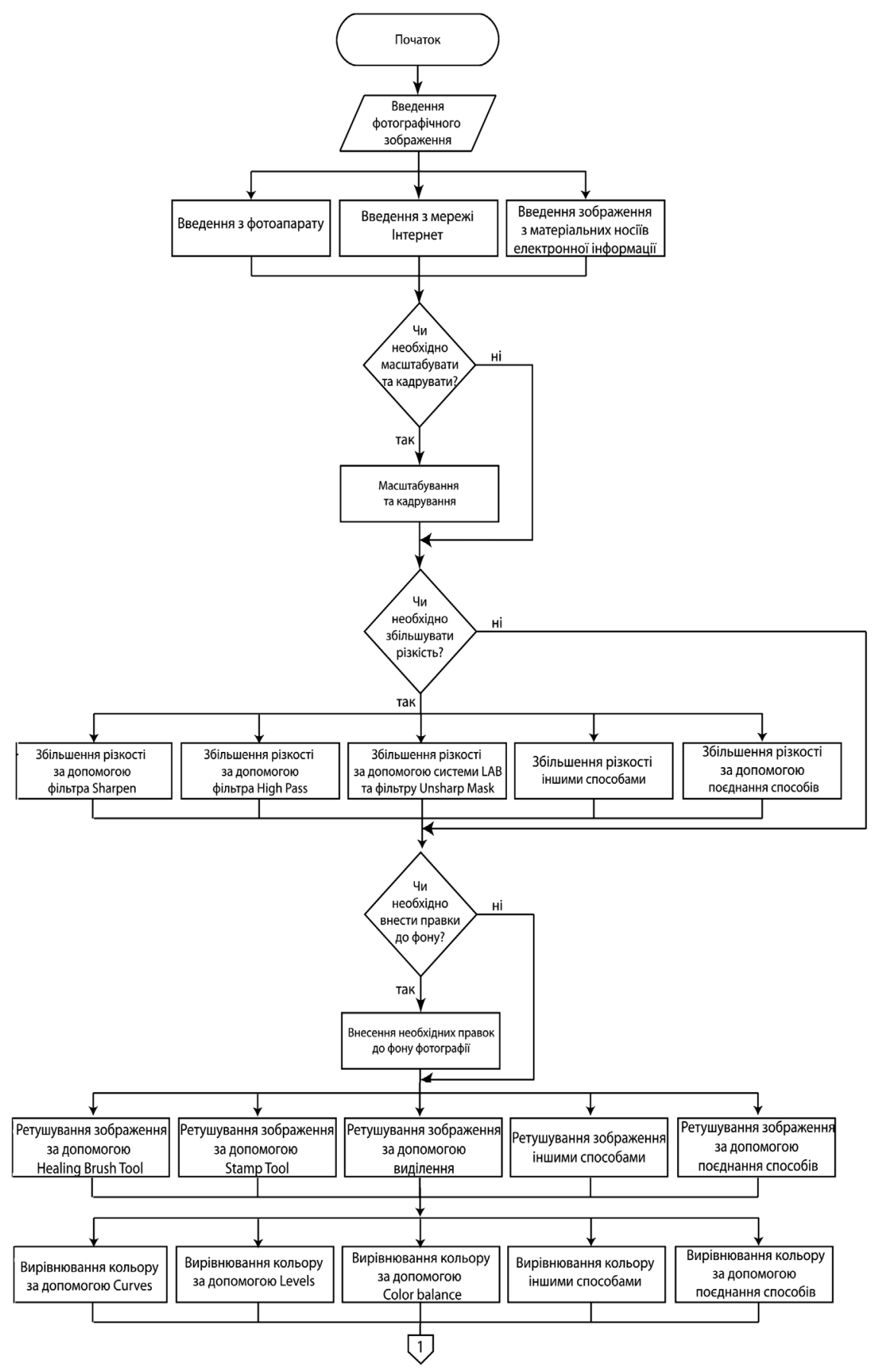

Рис. 7. Детальний алгоритм оброблення ЦФ в растровому графічному редакторі Adobe Photoshop. Початок 


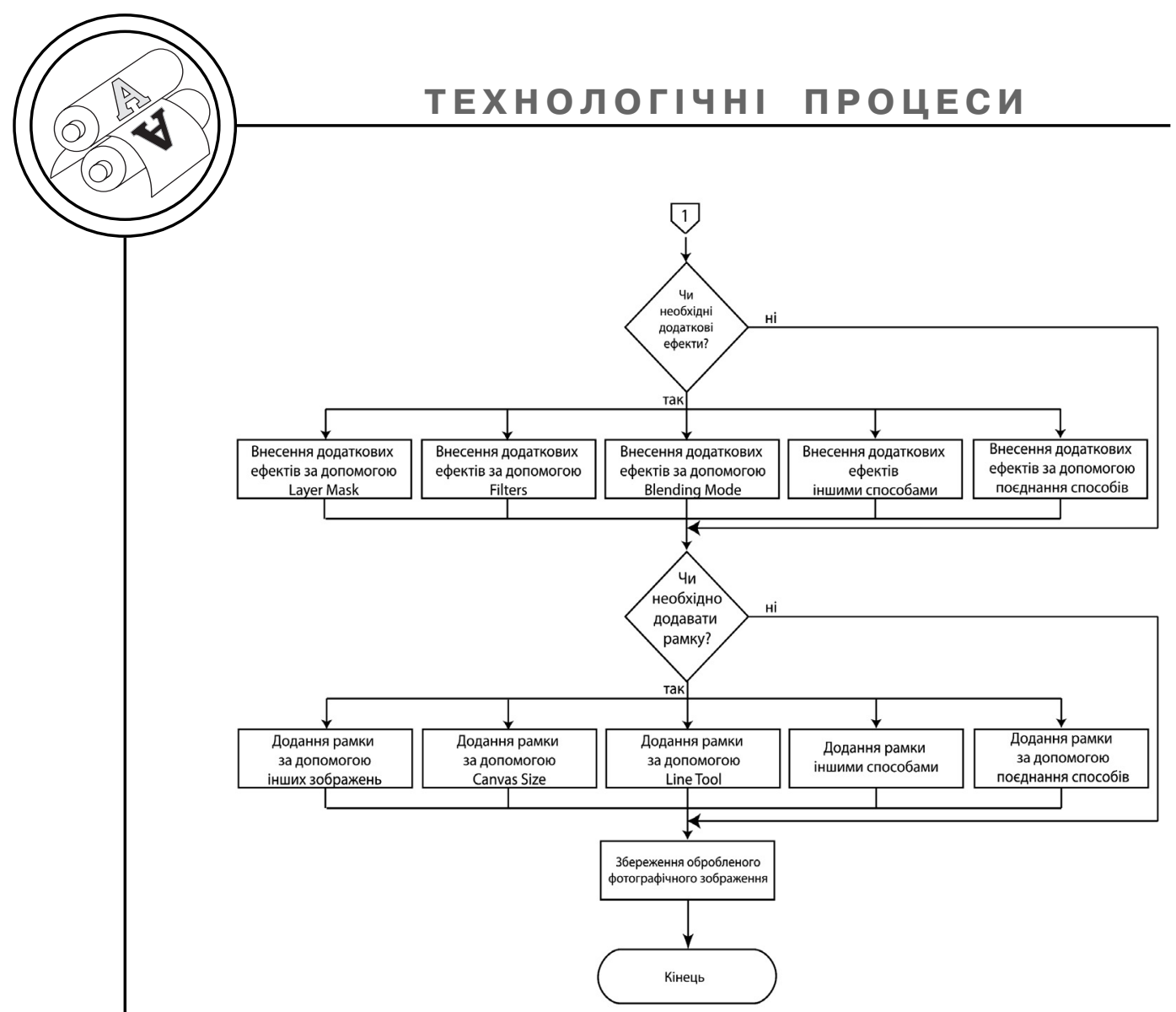

Рис. 7. Детальний алгоритм оброблення ЦФ в растровому графічному редакторі Adobe Photoshop. Закінчення

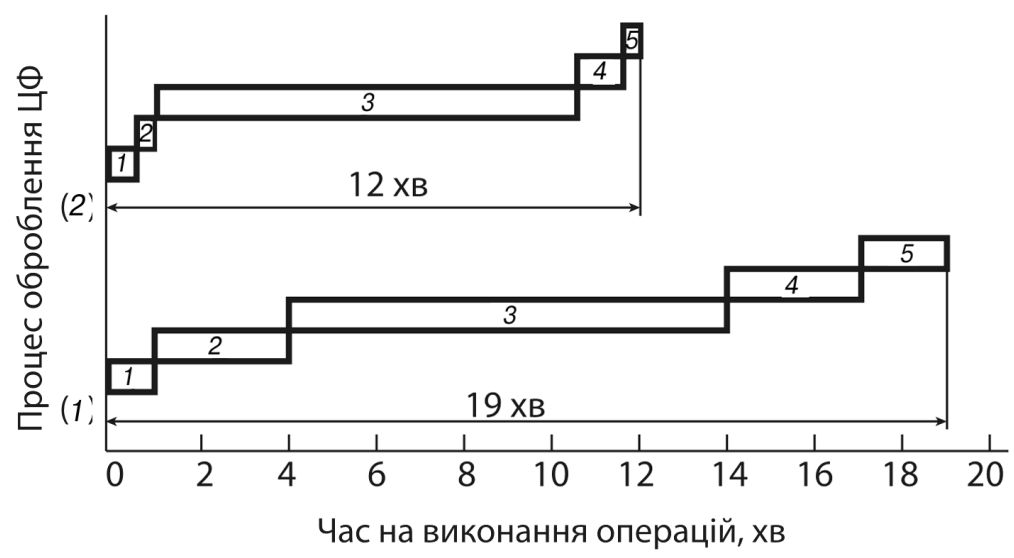

Рис. 8. Циклограма оброблення портрету без (1) та з (2) використанням комплексу макросів: 1 - відкриття ЦФ, операції масштабування та кадрування; 2 - наведення різкості; 3 - операції ретушування; 4 - тонота кольорокорекція; 5 - додання рамки навколо ЦФ 
ном кількість оброблюваних зображень за один період часу можна збільшити на $37 \%$.

\section{Висновки}

Отримані

результати дослідження параметрів, що впливають на якість ЦФ, апаратного та програмного забезпечення для створення та оброблення ЦФ, дають можливість оперативно встановлювати причини порушення якості ЦФ та обирати доцільне апа- ратне та програмне забезпечення для процесу створення та оброблення цифрових фотографічних зображень. Розроблені технологічний процес та детальний алгоритм забезпечують не лише покращення якості обробленого цифрового фото, а й скорочення часу на виконання типових операції, що дозволить уникнути зменшення уваги спеціаліста з оброблення ЦФ та підвищити продуктивність праці.

1. Дико Л. Бесіди в фотомайстернях / Л. Дико. - К. : Мистецтво, 2008. - 216 с. 2. Величко О. М. Проектування видавничо-поліграфічної справи. Практикум з проектування і розрахунку технологічних і виробничих процесів : навч. посіб. / О. М. Величко. -К. : ВПЦ «Київський університет», 2009. - 520 с. 3. Фельдман Я. Техника и технологии фотосъёмки / Я. Фельдман, Л. Курский. - М. : Лёгкая и пищевая промышленность, 2009. - 104 с. 4. Маргулис Д. Photoshop CS5 для профессионалов : классическое руководство по цветокоррекции / Д. Маргулис. - М. : РТВ-Медиа, 2001. - 400 с. 5. Лендер С. 100 \% самоучитель Adobe Photoshop / С. Лендер. - СПб. : Триумф, 2011. - 192 с. 6. Герасименко A. C. Adobe Photoshop CS 5. Профессиональные приемы работы / А. С. Герасименко. - СПб. : Триумф, 2008. - 384 с. 7. Таненбаум Э. Фотография в жизни / Э. Таненбаум. - СПб. : Питер, 2009. - 992 с.

1. Dyko L. Besidy v fotomaisterniakh / L. Dyko. - K. : Mystetstvo, 2008. 216 s. 2. Velychko O. M. Proektuvannia vydavnycho-polihrafichnoi spravy. Praktykum z proektuvannia i rozrakhunku tekhnolohichnykh i vyrobnychykh protsesiv : navch. posib. / O. M. Velychko. - K. : VPTs «Kyivskyi universytet», 2009. - 520 s. 3. Fel'dman Ja. Tehnika i tehnologii fotos'jomki / Ja. Fel'dman, L. Kurskij. - M. : Ljogkaja i pishhevaja promyshlennost', 2009. - $104 \mathrm{~s}$. 4. Margulis D. Photoshop CS5 dlja professionalov : klassicheskoe rukovodstvo po cvetokorrekcii / D. Margulis. - M. : RTV-Media, 2001. - 400 s. 5. Lender S. $100 \%$ samouchitel' Adobe Photoshop / S. Lender. - SPb. : Triumf, 2011. 192 s. 6. Gerasimenko A. S. Adobe Photoshop CS 5. Professional'nye priemy raboty / A. S. Gerasimenko. - SPb. : Triumf, 2008. - 384 s. 7. Tanenbaum Je. Fotografija v zhizni / Je. Tanenbaum. - SPb. : Piter, 2009. - $992 \mathrm{~s}$.

$$
\begin{array}{r}
\text { Рецензент - О. В. Зоренко, к.Т.н., } \\
\text { доцент, НТУУ «КПІ» }
\end{array}
$$

Надійшла до редакції 21.09.12 